\section{Detonography: Making of medieval mine print}

The Mining-Geology-Petroleum Engineering Bulletin UDC: 622.7

DOI: $10.17794 /$ rgn.2018.1.1

Preliminary communication

\author{
Siniša Stanković'; Matko Žbulj'; ; Vinko Škrlec ${ }^{3}$ \\ ${ }^{1}$ University of Zagreb, Faculty of Mining, Geology and Petroleum Engineering, Department of Mining Engineering and Geotechnics, \\ Pierottijeva 6, HR-10000 Zagreb, Croatia, Expert Associate \\ ${ }^{2}$ University of Zagreb, Faculty of Mining, Geology and Petroleum Engineering, Department of Mining Engineering and Geotechnics, \\ Pierottijeva 6, HR-10000 Zagreb, Croatia, Student \\ ${ }^{3}$ University of Zagreb, Faculty of Mining, Geology and Petroleum Engineering, Department of Mining Engineering and Geotechnics, \\ Pierottijeva 6, HR-10000 Zagreb, Croatia, Assistant Professor
}

\begin{abstract}
Using the energy of explosion, a print of the picture "Medieval mine" onto an aluminium plate was made. This is one version of a technique called Detonography. It has been introduced and developed by Evelyn Rosenberg with a number of her colleagues, based on the "Munroe effect". To determine the optimal parameters of explosive performance and supporting materials, a large number of laboratory testing has been made on smaller samples.
\end{abstract}

\title{
Keywords
}

Detonography, explosives, art

\section{Introduction}

The use of explosives as a high-energy source in the metals field and energetic materials has developed from an interesting curiosity to metal working reality, with extensive possibilities now existing in a wide range of industries. Explosive metal working operations now include the forming, sizing, flanging, engraving, compacting, welding, hardening, and cutting of metals (Rinehart and Pearson 1963). Detonography as a blast-produced art has been developed by Evelyn Rosenberg with several of her colleagues, based on the "Munroe effect", which is also known as the "von Foerster effect" in Europe (Kennedy 1990). It acts as a perfect medium for transferring pictures into a new form of art (Rosenberg 2013). To test this phenomenon, it has been decided to make a print of a less complex picture "Medieval mine" onto an aluminium plate. To achieve that, a number of different parameters had to be determined by conducting laboratory testing on smaller samples.

The final product is exhibited within faculty walls.

\section{Background}

The history of shaped charge will bring us from Franz von Baader (1792) to Charles E. Munroe who rediscovered the hollow cavity i.e., the unlined shaped charge

Corresponding author: Siniša Stanković

sinisa.stankovic@oblak.rgn.hr
(Walters and Zukas 1989). Charles E. Munroe, professor of chemistry at Columbian University, in conducting his experiments at the Naval Torpedo Station in 1888, noted that explosive waves tended in certain cases to reinforce each other. His discovery was made quite by accident. Professor Munroe used to mark blocks of molded guncotton for identification by countersinking letters into the surface of the blocks. When such blocks were laid upon a steel plate and exploded, Dr. Munroe noted that letters were reproduced upon the iron plate. That phenomenon called the "Munroe effect" has enhanced the development of "shaped charges" (Maisel 1944). Experimentally, he placed leaves, bits of lace, coins, and stencils between the gunpowder and the metal plates and succeeded in producing raised ornamental designs on the surface of the plates by setting off an explosive (Torrey 1945). An artist Verner Molin developed a technique he called explosive engraving - a sensitive and effective way to meet his objectives as a portraitist (Molin 1979). Gideon Sivan, a talented explosive engineer had been testing this phenomenon for years when in 1985 he met Evelyn Rosenberg who was working as a printmaker at that time. They combined their knowledge of art and blasting and started to develop what is today called detonography. It is the creation of art using explosives and metal (Rosenberg 2013). Since 1985 to date, Evelyn Rosenberg has improved detonography in many different aspects to make it as it is today. Her arts, made in the aforementioned technique, decorate many public buildings in the United States (Sućeska 2001). 
Table 1: Properties of ANFO explosive

\begin{tabular}{|l|l|}
\hline Properties & ANFO \\
\hline Density $\left(\mathrm{g} / \mathrm{cm}^{3}\right)$ & $0.90-0.95$ \\
\hline Detonation velocity $(\mathrm{m} / \mathrm{s})$ & $2000-2500$ \\
\hline Detonation transmission $(\mathrm{cm})$ & Contact \\
\hline Oxygen balance $(\%)$ & +0.11 \\
\hline Gas volume $\left(\mathrm{dm}^{3} / \mathrm{kg}\right)$ & 990 \\
\hline Heat of explosion $(\mathrm{kJ} / \mathrm{kg})$ & 4250 \\
\hline Explosion temperature $(\mathrm{K})$ & 2700 \\
\hline Initiation & Pentolite booster $300 \mathrm{~g}$ \\
\hline
\end{tabular}

Table 2: Sieve analysis of ground ANFO explosive

\begin{tabular}{|l|c|c|c|c|}
\hline $\begin{array}{l}\text { Sieve } \\
\text { size } \\
(\mathrm{mm})\end{array}$ & $\begin{array}{c}\text { Mas } \\
\text { retained } \\
(\mathrm{g})\end{array}$ & $\begin{array}{c}\text { Percentage } \\
\text { retained } \\
(\%)\end{array}$ & $\begin{array}{c}\text { Cumulative } \\
\text { percentage } \\
\text { retained }(\%)\end{array}$ & $\begin{array}{c}\text { Percentage } \\
\text { passing }(\%)\end{array}$ \\
\hline 0,5 & 0,00 & 0,00 & 0,00 & 100,00 \\
\hline 0,25 & 51,29 & 27,27 & 27,27 & 72,73 \\
\hline 0,15 & 61,41 & 32,65 & 59,92 & 40,08 \\
\hline 0,075 & 71,23 & 37,87 & 97,79 & 2,21 \\
\hline 0,01 & 4,16 & 2,21 & 100,00 & 0,00 \\
\hline
\end{tabular}

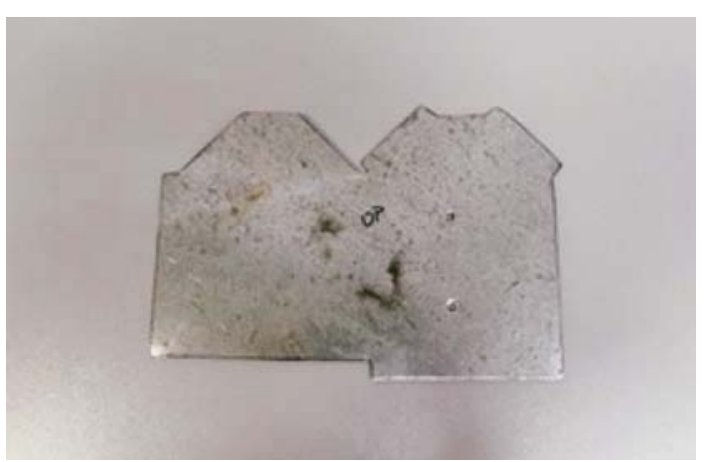

\section{Laboratory tests and results}

All tests have been conducted in the Laboratory for testing explosive materials, in the Department of Mining Engineering and Geotechnics at the Faculty of Mining, Geology and Petroleum Engineering, at the University of Zagreb.

These tests included a large number of trials to determine the optimal blasting parameters as well as favorable explosive and auxiliary materials and their relations. The results of the trials will be used for making a print of a picture on a larger scale.

Unlike detonography described in the works of Evelyn Rosenberg, explosive materials used and their order (layers) were different. The major difference was that a mould was above the metal plate and made of linoleum instead of plaster. The picture for this detonograph has been found on Google images search page.

For the laboratory tests, an ANFO explosive has been used with properties as shown in Table 1.

Ammonium Nitrate has been ground to fine particles and then mixed with Fuel Oil in a volume ratio of Am-

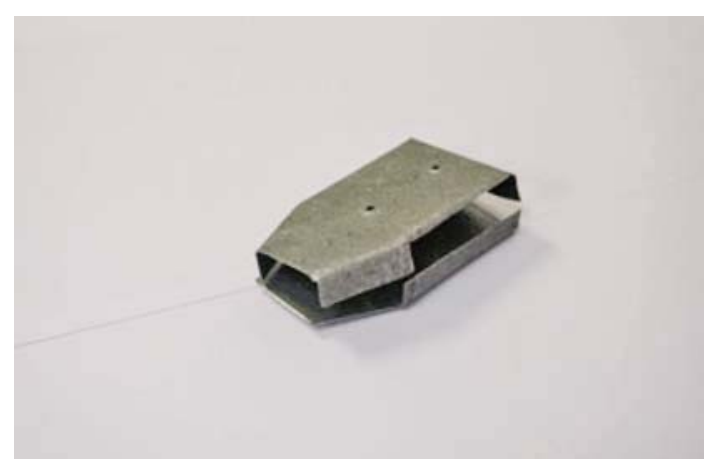

Figure 1: Steel zinc coated tin casing

Table 3: Test results depending on explosive charge

\begin{tabular}{|l|c|c|c|c|l|}
\hline No. & $\begin{array}{c}\text { Mass of } \\
\text { explosive } \\
\text { used }(\mathrm{g})\end{array}$ & $\begin{array}{c}\text { Surface } \\
\text { of metal } \\
\text { cube }\left(\mathrm{cm}^{2}\right)\end{array}$ & $\begin{array}{c}\text { Velocity of } \\
\text { detonation } \\
(\mathrm{m} / \mathrm{s})\end{array}$ & $\begin{array}{c}\text { Concentration } \\
\text { of explosive per } \\
\text { surface }\left(\mathrm{g} / \mathrm{cm}^{2}\right)\end{array}$ & Distribution of components \\
\hline 1. & 42,95 & 35,00 & 2112 & 1,23 & Hard linoleum with linocut, aluminium cube, two layers of rubber \\
\hline 2. & 39,40 & 35,00 & 2564 & 1,13 & Hard linoleum with linocut, aluminium cube, two layers of rubber \\
\hline 3. & 41,31 & 35,00 & 6818 & 1,18 & Hard linoleum, leaf, aluminium cube, two layers of rubber \\
\hline 4. & 41,46 & 35,00 & 1604 & 1,18 & Hard linoleum with linocut, aluminium cube, two layers of rubber \\
\hline 5. & 38,92 & 35,00 & - & 1,11 & Soft linoleum with linocut, aluminium cube, two layers of rubber \\
\hline 6. & 41,18 & 35,00 & 3030 & 1,17 & $\begin{array}{l}\text { Soft linoleum, soft linoleum with linocut, aluminium cube, } \\
\text { two layers of rubber }\end{array}$ \\
\hline 7. & 42,67 & 35,00 & 1973 & 1,22 & $\begin{array}{l}\text { Two layers of soft linoleum, soft linoleum with linocut, aluminium } \\
\text { cube, two layers of rubber }\end{array}$ \\
\hline 8. & 44,41 & 35,00 & 2857 & 1,27 & Rubber, carved rubber, aluminium cube, two layers of rubber \\
\hline 9. & 45,06 & 35,00 & 2290 & 1,29 & $\begin{array}{l}\text { Rubber, soft linoleum with linocut, aluminium cube, two layers } \\
\text { of rubber }\end{array}$ \\
\hline 10. & 41,77 & 35,00 & - & 1,19 & Hard linoleum with linocut, aluminium cube, two layers of rubber \\
\hline 11. & 42,09 & 35,00 & - & 1,19 & $\begin{array}{l}\text { Soft linoleum, hard linoleum with linocut, aluminium cube, } \\
\text { two layers of rubber }\end{array}$ \\
\hline 12. & 42,07 & 35,00 & - & 1,20 & $\begin{array}{l}\text { Soft linoleum, hard linoleum with linocut, aluminium cube, } \\
\text { two layers of rubber }\end{array}$ \\
\hline
\end{tabular}




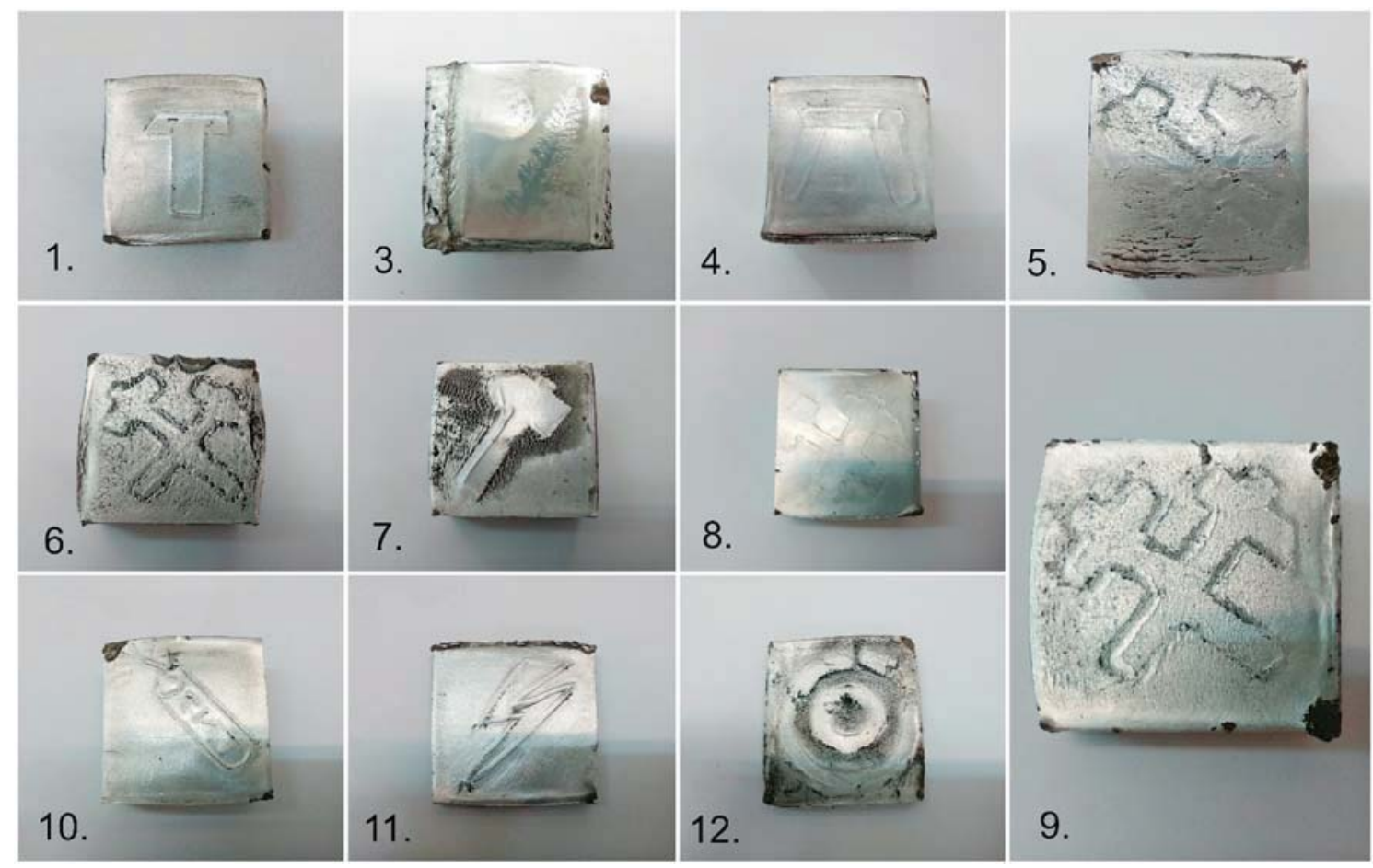

Figure 2: Results of laboratory tests (Žbulj, 2016)

monium Nitrate 94\% / Fuel Oil 6\%. The density of the ANFO explosive used for tests is $0,914 \mathrm{~g} / \mathrm{cm} 3$. A sieve analysis of the ANFO explosive is shown in Table 2.

Since ANFO explosives need a confined space for stable detonation, a casing had to be made. For testing purposes, small casing were cut from $1 \mathrm{~mm}$ thick steel zinc coated tin and folded as shown in Figure 1. In the top part of the casing, two small holes were drilled with a $30 \mathrm{~mm}$ spacing to insert optical probes for measuring the VOD of the explosive inside. The front part of the casing is constructed in such a way to ensure a creation of a straight detonation wave throughout the casing and as such ensuring consistent activity of the explosive's energy on the whole surface of a print. In this way, the transfer of a negative image onto the metal plate is uniform.

Several different symbols transferred to linoleum/ rubber material, were used for testing purposes.

The main parameter to be determined is a specific quantity of explosive per square meter of a blasting surface. Twelve tests have been done with different quantities of explosives, different positions of explosives, auxiliary materials and metal plate/cube (see Table 3, Figure 2)

The best results were achieved in test no. 11 and as such they were used as a basis for the creation of the "Medieval mine" print.

\section{Making the relief of a medieval mine}

After the determination of all the required parameters, preparatory work for the main event commenced. First, the picture of the medieval mine had to be stretched to

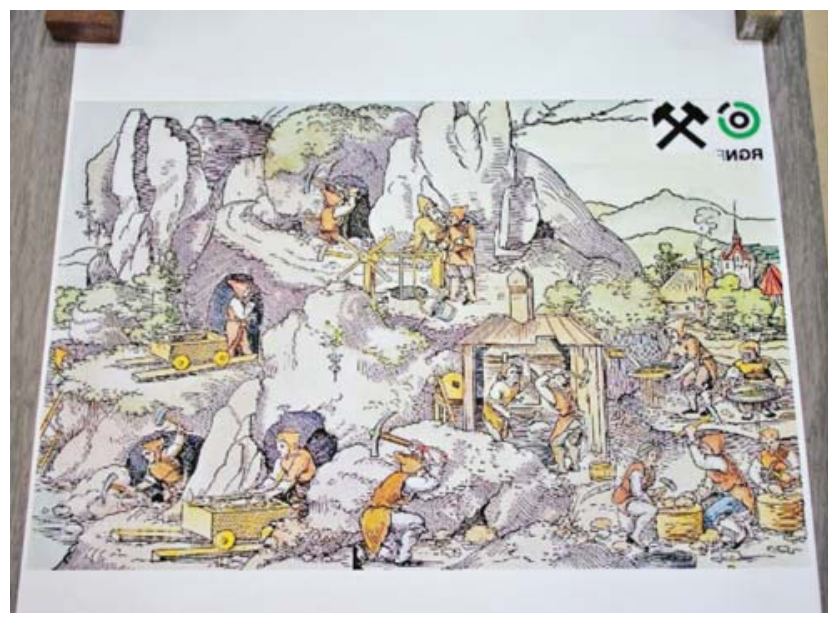

Figure 3: Enlarged negative image

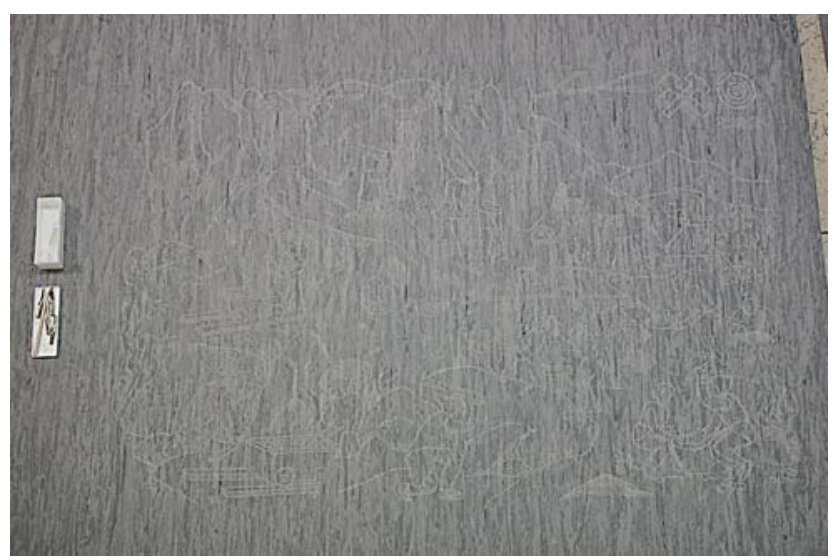

Figure 4: Linocut in negative 


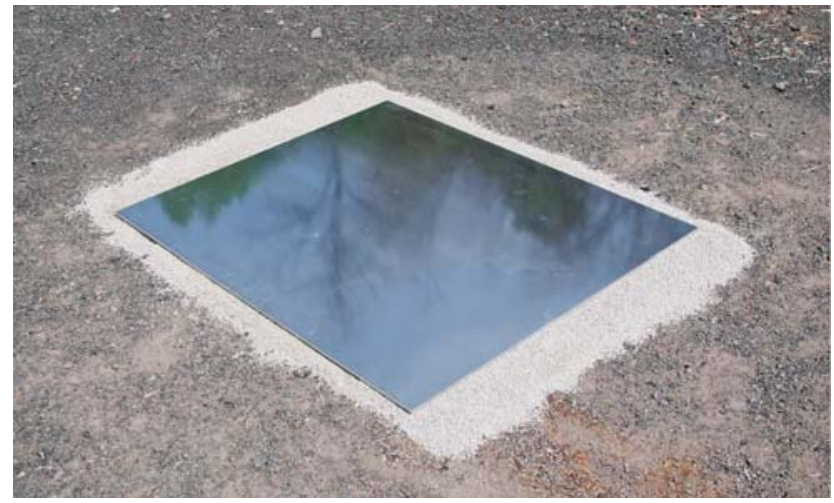

Figure 5: Aluminium plate on sand-like material

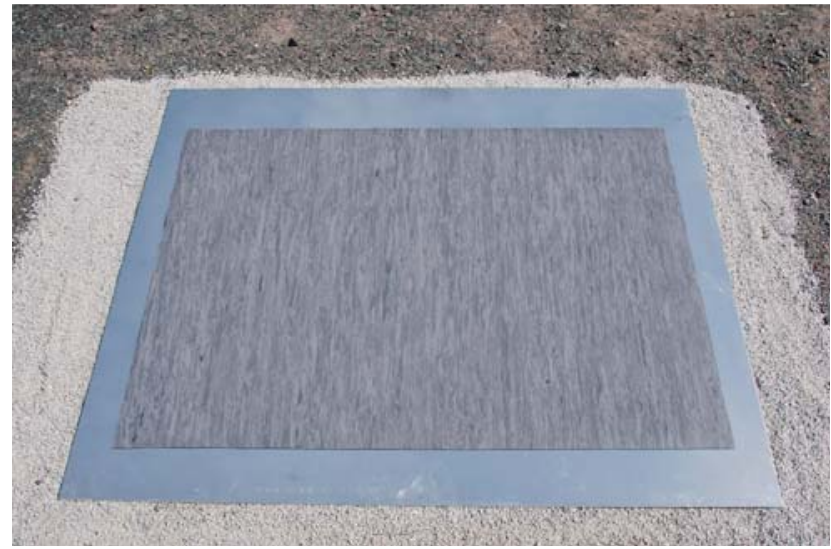

Figure 6: Aluminium plate on sandlike material

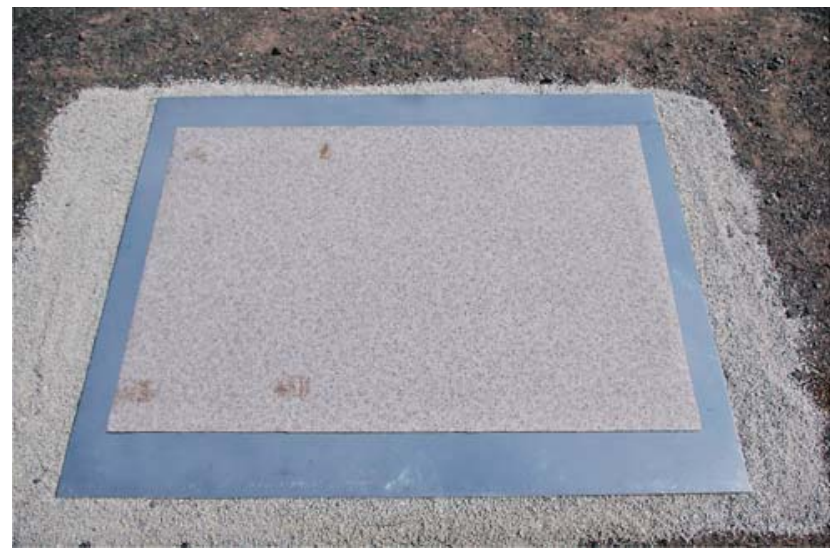

Figure 7: Soft linoleum covering linocut

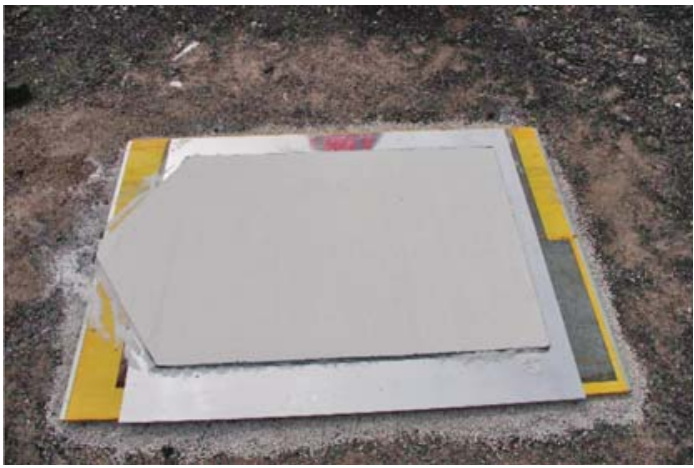

Table 4: Properties of AMONEX 1 explosive

\begin{tabular}{|l|l|}
\hline Properties & AMONEX 1 \\
\hline Density $\left(\mathrm{g} / \mathrm{cm}^{3}\right)$ & $1,06 \pm 0,04$ \\
\hline Detonation velocity $(\mathrm{m} / \mathrm{s})$ & $\min .4100$ \\
\hline Detonation transmission $(\mathrm{cm})$ & $\min .4$ \\
\hline Oxygen balance $(\%)$ & $+0,13$ \\
\hline Gas volume $\left(\mathrm{dm}^{3} / \mathrm{kg}\right)$ & 975 \\
\hline Heat of explosion $(\mathrm{kJ} / \mathrm{kg})$ & 4103 \\
\hline Explosion temperature $(\mathrm{K})$ & 2740 \\
\hline Initiation & Blasting Cap $\mathrm{N}^{\circ} 8$ \\
\hline
\end{tabular}

the size of an aluminium plate $1,0 \mathrm{~m} \times 1,2 \mathrm{~m}$, the faculty and mining symbol was added and then the picture was turned into a negative image (see Figure 3). The next step was cutting the negative along the major lines with a scalpel, and transferring it to the linoleum material.

Linocut, a printing technique in which a sheet of linoleum is used for a relief surface, has been utilized to make a mould. Besides the major lines transferred directly from a negative of the picture, all the details from it were additionally added by hand (see Figure 4).

The last of preparatory work was mixing a large enough quantity of ground ANFO explosive and we were all set for field work.

Firstly, due to the uneven surface, to prevent any damage to the aluminium plate during the blast, a layer of sand-like material was placed on the ground (see Figure 5).

Using the results of laboratory tests, the layers were distributed in the following order:

1. On the bottom, laid directly on the sand-like material, was the aluminium plate

2. On the plate, linoleum with a negative relief was placed face down (see Figure 6)

3. The third layer was a softer type of linoleum (see Figure 7)

4. The fourth layer was an aluminium sheet casing filled with the ANFO explosive (see Figure 8)

The electric detonator was attached to the explosive and connected to electrical wires which allowed for detonation from a safe distance.

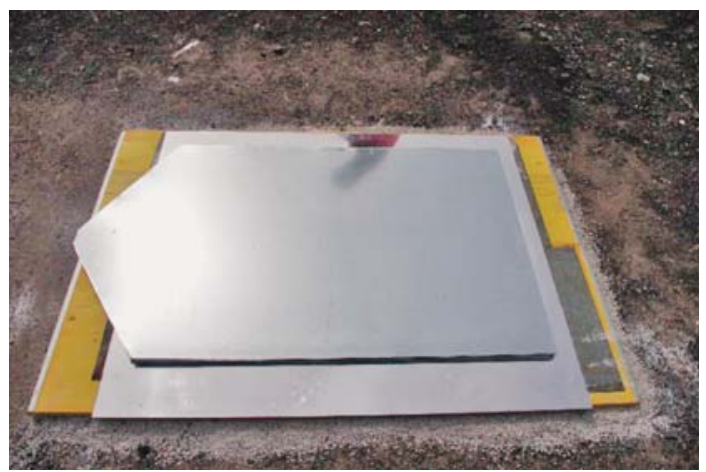

Figure 8: Aluminium sheet casing filled with ground ANFO explosive 

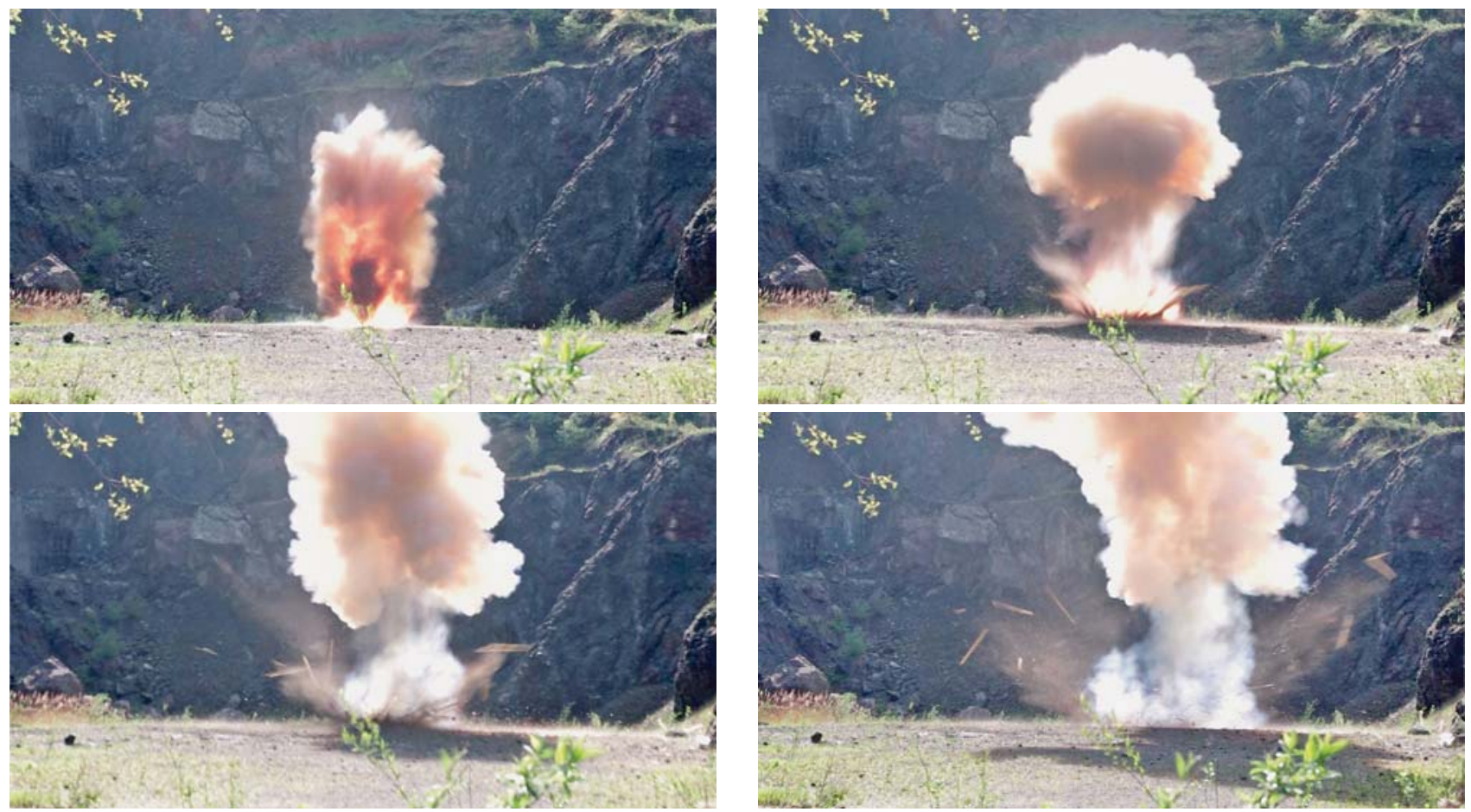

Figure 9: Detonation of explosive

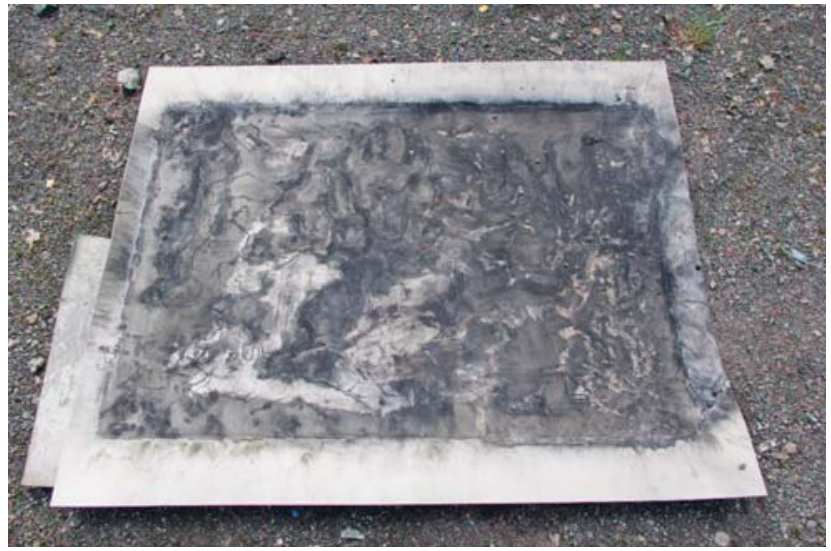

Figure 10: Detonograph after blasting

Due to the aforementioned characteristic of the ANFO explosive to need a confined space for stable detonation, the first blast was unsuccessful, it blew open the casing and thus interrupted the detonation wave. Fortunately, only the casing cover was destroyed during the blast.

For the second blast, Amonex 1 explosive was used, which unlike the ANFO explosive, can be detonated in an open space. Amonex 1 is a TNT/ammonium nitrate based powdered explosive with properties as shown in Table 4.

The second blast (see Figure 9) was successful. The detonation wave forced the aluminium plate to fill the linoleum mould, thus leaving a relief of the medieval mine (see Figure 10). The aluminium plate was washed clean, ink-coloured and protected with a clear coat (see Figure 11).

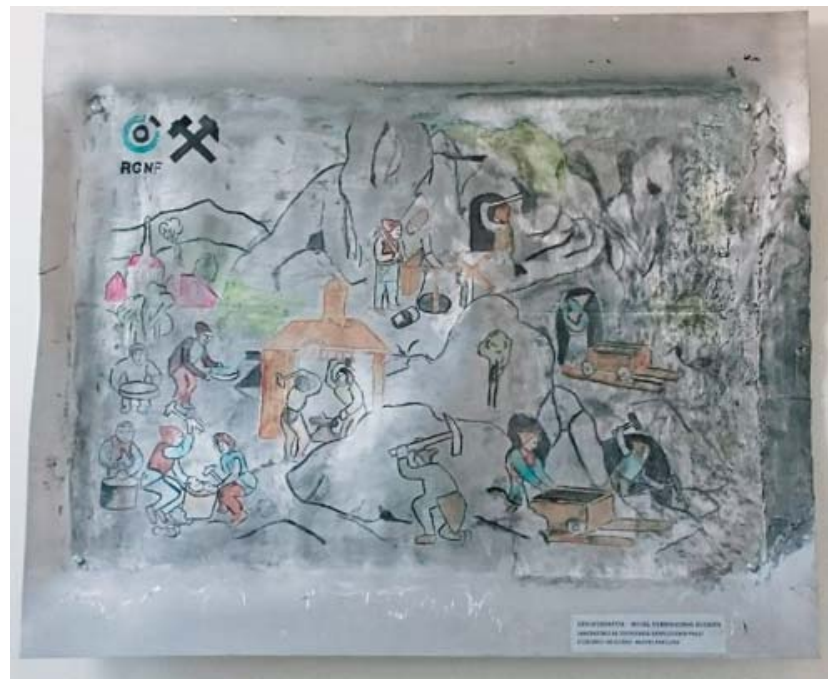

Figure 11: Detonograph washed clean, ink-coloured and protected with a clear coat

\section{Conclusions}

Detonography as a relatively new discipline shows that explosives are not only for military and civil use but also for art. The results of the laboratory tests show that the optimal concentration of explosives per surface is $1,19 \mathrm{~g} / \mathrm{cm}^{2}$ and the optimal distribution of components in the following order from top to bottom are: explosive charge in casing, soft linoleum, hard linoleum with linocut, aluminium cube and two layers of rubber. Furthermore, powdered explosives can be used as well for making a print and not only rubberized $\mathrm{C}$-1 explosive as described in literature. 
This successful experiment showed that when you determine the optimal parameters, art is born. It, of course, still needs further research with different parameters, materials and explosives to be able to make more complex reliefs.

\section{References}

\section{Published references:}

Rinehart, J.S., Pearson, J. (1963): Explosive working of metals. Pergamon Press ltd, London, $345 \mathrm{p}$

Rosenberg, E (2013): Detonography, the explosive art of Evelyn Rosenberg. University of New Mexico Press, Albuquerque, $98 \mathrm{p}$

Sućeska, M. (2001): Eksplozije i eksplozivi, njihova mirnodopska primjena. Brodarski institute, Zagreb, $303 \mathrm{p}$
Walters, W.P., Zukas, J.A. (1989): Fundamentals of shaped charge. Wiley-Interscience, USA, 398 p

Žbulj, M (2016): Detonografija. Završni rad, Rudarsko-geološko-naftni fakultet, Sveučilišta u Zagrebu

Kennedy, D. R. (1990): History of the shaped charge effect, the first 100 years. MBB Schrobenhausen, West Germany

Maisel, A.Q. (1944): Teaching explosives to do tricks. Popular science, May 1944, 132

Molin, V. (1979): A new engraving technique by means of eksplosives. Leonardo 12, no. 3, 222

Torrey, V. (1945): The Bazooka's Grandfather. Popular science, February 1945, 65

\section{Internet source:}

https://www.google.hr/search (12.05.2016.)

\section{SAŽETAK}

\section{Detonografija: izradba otiska srednjovjekovnoga rudnika}

Koristeći se energijom eksploziva napravljen je otisak slike srednjovjekovnoga rudnika na aluminijsku ploču. Riječ je o verziji tehnike koja se zove detonografija. Uvela ju je i razvila Evelyn Rosenberg u suradnji s nekoliko kolega, a na temelju Munroeva efekta. Za određivanje optimalnih parametara učinka eksploziva i pratećih materijala izveden je velik broj laboratorijskih ispitivanja na manjim uzorcima.

\section{Ključne riječi}

detonografija, eksplozivi, umjetnost

\section{Author(s) contribution}

Siniša Stanković - research, concept development, determination of method, analysis of the results, performing the experimental part, wrote an article. Matko Žbulj - determination of method, analysis of the results, partially participated in the experimental part. Vinko Škrlec - analysis of the results, performing the experimental part. 